(ratio space charge field to applied field) are intellectually unsatisfying. The whole basis of the quantitative theory has been subjected to severe criticism (Zeleny, J. App. Phys., 13, 444).

The book generally presents a complex argument clearly, but exception might be taken to the use of the terms 'retrograde streamer', 'positive streamer' and 'negative streamer', since all the streamers described contain negative and positive particles and the direction of growth is always towards the cathode. This contribution marks a step forward in our knowledge of sparking mechanisms; but the end of the story is not yet in sight.

R. Davis

1016

\section{TRADE MARKS IN INDIA}

The Law and Practice under the Trade Marks Act, 1940

(As amended by the Trad Marks (Amendment) Acts of 1941 and 1943); with a Full Collection of Statutes, Rules, Forms and PAcedents, and a Guide to the Classification of Grods under the Trade Marks Act, 1940. By Dr. S. Tenkateswaran. Pp. Ixxvii+1,128. (Calcutta : Eastern Law House, Ltd., 1945.) 30 rupees.

A T a tho when India is about to become selfA goverfing and replace outside influences by Ind $M$ it is not uninteresting to note that only so redontly as 1940 India adopted, almost entirely, the En lish law relating to the registration of trade marks. It is, however, somewhat startling to realize that a country with such strong commercial interests as India should have managed without registered trade marks until that date, and that traders were obliged to rely on cumbersome and expensive passing. off actions to protect their name and goods. Appar. ently until after the First World War attempts at legislation in that direction met with only lukewarm encouragement, and it was not until the 'twenties that the matter received popular support from the Indian commercial public.

This delay has not been wholly unfavourable to India, as they have been able to avoid the trials and errors of the earlier English trade mark Acts and have adopted. English trade mark law as it stands to-day. The Indian Trade Mark Act, 1940 (as amended by the Acts of 1941 and 1943), is based on the Trade Marks Act, 1938, and where it departs from English law is (with one or two exceptions) mainly for administrative purposes; and in fundamental legal principles it follows the English statute, adopting the innovations, such as registered users, defensive registration, assignment with or without the goodwill of a business, which were introduced by the Trade Marks Act of 1938.

The author of the present volume, Dr. S. Venkateswaran, has compiled what may well become a standard work on the subject, if the law remains substantially unaltered, and it is scarcely likely that registration of trade marks will be renounced so long as individual trading is protected. The form of the text consists in stating the sections of the Act, and following each section with exhaustive notes on the English case law dealing with the particular principle, and giving some history of the corresponding section of the English Act. These notes are possibly too detailed and elaborate, and a person unacquainted with the subject may find it difficult to use this book as a reference book; but this is a minor fault, as the arrangement and indexing has been done with great care and, on the whole, admirable clarity. Notwithstanding that Dr. Venkateswaran says in the preface that the English cases cited "are of value only insofar as they lay down the principles of law and give guidance on the construction of the section", the quotations from English case law are encyclopædic and as up-to-date as is possible in a book which must take some time in going through the press, and are an exceedingly valuable guide to the judicial interpretation of English trade mark law. It is to be hoped, however, that if in future editions notes of Indian judicial decisions are given in equal length, the author will not forbear to cut or condense some of his earlier notes, as this book (1,128 pages in all) is as large as is convenient for any text-book.

The book covers the whole of the Trade Marks Act and includes the substantive law and procedure relating to the registration of trade marks, the essential requirements for the registration of a trade mark, rectification and correction of the register, the duration and assignment of trade marks, the action for infringement and specialized types of registration, such as certification marks, for example.

The arrangement of the book has been well done, both as to text, appendixes and index; the appendixes, besides containing the Act and Rules, tables comparing the Indian Act with the English Acts of 1905 and 1938, have much useful information relating to pleadings and forms and orders used in English trade mark cases.

Irene G. R. Moses

\section{TRUTH AND ITS EXPRESSION}

\section{In Search of Trupt}

By Dr. Abel J. (Discussion Books, No. 79.) Pp. 208. (Lordon and Edinburgh : Thomas Nelson and Sorsud 1945.) 3s. 6d. net.

R. (ABEL J. JONES'S volume rightly appears 1 in 4 series of "Discussion Books". He never lays lown the law, but offers an abundance-perhaps a sup rabundance of material designed to set the reader thinking. His aim has been to give an account of the way in which men of science, historians, philosophers, artists, poets, moral and religious teachers and others have searched for truth and tried to express it. $\mathrm{He}$ admits that some readers may find the treatment too brief, but hopes they may find the book of interest as a conspectus of the whole subject. Indeed the reviewer, after an attentive perusal, has come to regard the book as a handy directory, written by a person of wide sympathies and encyclopædic reading, and he proposes to give it a place among his reference books. Here he can only offer a few comments. The chapter on "The Liars in their Lairs" is both diverting and incisive. The author quotes to good effect the philosopher who said, "if you ask me what time is I cannot tell you, but I know what it is if you do not ask me". It will be news to many that Mussolini founded his morality on the pragmatism of William James. The sections on our habits of labelling and on "the bondage of consistency" are much to the point. The one chapter which the reviewer finds inadequate is that on historical truth, where no account is taken of the positions held by G. M. Trevelyan, J. B. Bury, J. Buchan, and others. 